INTERNATIONAL JOURNAL OF RESEARCHES IN BIOSCIENCES, AGRICULTURE AND TECHNOLOGY C VISHWASHANTI MULTIPURPOSE SOCIETY (Global Peace Multipurpose Society) R. No. MH-659/13(N) www.vmsindia.org

\title{
RESPONSE OF HYBRID COTTON TO APPLIED GYPSUM, FYM AND PMC UNDER SPRINKLER IRRIGATIN WITH ALKALI WATER
}

\author{
V. P. Babhulkar, S. U. Charjan and P. C. Pagar \\ College of Agriculture, Nagpur- (M.S.) India \\ Deptt of Agril. Chemistry and Soil Science \\ Dr. Panjabrao Deshmukh Krishi Vidyapeeth, \\ Akola, Maharashtra- 444104
}

\begin{abstract}
:
Well water of Purna valley of Vidarbha region (Maharashtra) is marginally alkali to alkali in nature. Under sprinkler irrigation with alkali water (EC $2.90 \mathrm{dsm}^{-1}$, SAR 27.30 and RSC 7.4 meqvL-1), the response of Hr. Cotton (Cv. Nandet44) grown on saline-sodic Vertisols (pHs 8.2, Ece $2.01 \mathrm{dsm}^{-1} \&$ SARe 16./00 meqv. ${ }^{\mathrm{L}-1}$ ) to applied gypsum, FYM and PMC was studied on farmers fie $\backslash d$ m RBD during 1996-97 and observed that application of gypsum @ 50 and $100 \%$ GR enhanced significantly the seed cotton yield over control. However, both levels of gypsum were at par. Combinations of gypsum @ 50 \% GR + FYM @ 5 t ha'1 or gypsum @ 50 \% GR + PMC @ 2.5 t ha'1 found better as compared to gypsum alone in respect of increasing seed cotton yield (44-46\% over control) and reducing the pHs, ECe an SARe of saline-Socic Vertisols of Purna valley. Thus sustained yields are possible under alkali water with the addition of gypsum along with FYM or PMC.
\end{abstract}

Keywords: Alkali water, Saline-Sodic soil, gypsum, FYM, PMC

\section{Introduction:}

Purna valley is well known unique saline tract of Vidarbha region of Maharashtra, covering an area of above-18,300 km2. The well and river water of this tract, are not safe for irrigating the deep, ill drained and saline-sodic Vertisols of the tract; continuous use of such water hasten modification process that may adversely affect the productivity of the tract (Nimkar et al 1992). In addition to chemical composition of the water, the deteriorations vary with soil texture, mineralogy and salt release characteristics of soil (Shainberg and Latey, 1984). The ameliorating effect of gypsum in sodic Vertisols is well known (Sagare et al. 1996). The present investigation was planned to evaluate the quality of well water of Purna valley and to study interactive effect of Gypsum PMC and FYM on soil properties and yield of seed Cotton grown on saline-sodic Vertisols.

\section{Materials and Methods:}

Well water samples from various locations of Purna valley tract of Vidarbha region (Maharashtra) were collected in summer (May) and winter seasons (November), analysed for quality indices and classified into various quality classes of water (CSSRI1994).

A field trial in RBD was conducted during 1996-97 envolving Hy. cotton (CV. Nanded - 44) as a test crop grown on salinesodic Vertisols (pHs 8.2, ECe $2.01 \mathrm{dsm}^{-1}$ and SARe 16.00 meqv $\mathrm{L}^{-1}$ ) of PUrna valley of Vidarbha region. The alkali water (ECe 2.90 $\mathrm{dsm}^{-1}$, SAR 27.30 and RSC $7.4 \mathrm{~m}$ equiv. $\mathrm{L}^{-1}$ )of valley had been used for sprinkler irrigations in the said soil for the last 6 years with variable crop rotations. Treatments (seven in number, replicated four times) comprised of control (no amendments), Gypsum @50 and 100\% Gr. FYM @ 5 t ha-1 PMC @2.5 t ha-1 1, Gypsum @ $50 \%+$ FYM@5 t ha-1 PMC@2.5 Recommended levels of fertilizers (100.50:50 kg N, $\mathrm{P}_{2} \mathrm{O}^{5}$ and $\mathrm{K}^{2} \mathrm{O} \mathrm{ha}^{-1}$ respectively) were applied to all plots. Soil samples were collected after harvest of crop and analysed for $\mathrm{pH}$ of saturated paste, electrolyte conductivity and SAR of paste extracts and quality indices of well water. EC, RSC and SAR were determined by adopting standard procedures (Richards./ 1954).

\section{Results and Discussion:}

As per the criteria, suggested by CSSRI (1994), Karnal well water samples collected from various locations of Purna valley are marginally Alkali to alkali in nature (Table 1)

The respective values for electrolyte conductivity, sodium adsorption ratio and residual sodium carbonate were 0.27-3.9 $\mathrm{dsm}^{-1}$ 9.2- 27.3 and $2.6-9.4$ meqv. L-1. Tanpure et. al (1977) also reported the $\mathrm{pH}, \mathrm{EC}, \mathrm{SAR}$ and RSC of Purna valley well water in the range of 7.7 $9.00 .55-15.5 \mathrm{dsm}^{-1}, 0.38-45.7$ and 1.23 to 16.36 meqv $^{-1}$ respectively and noticed that majority of well water samples were not safe for irrigation, Date, further indicated that EC, SAR and RSC of well water increased in summer as compared to winter and this might be attributed to increase in concentration of well water during summer season. 
Data (Table 2) further revealed that application of Gypsum, FYM and PMC alone and their combinations enhanced seed cotton yield significantly over control (No amendments) under sprinkler irrigation with alkali water. Within the Gypsum levels addition of Gypsum (a.50\% GR and 100\% GR enhanced seed cotton yield significantly over control. However, both the levels of Gypsum were at par with each other, indicating no more beneficial effect of Gypsum @100\% GR over Gypsum @ $50 \%$ GR in respect of seed cotton yield. Results showed that combinations of Gypsum @ $050 \%$ GR+FYM @ 5.1 ha-1 or Gypsum @ $50 \%$ GR +PMC @2.5 t ha ${ }^{-1}$ were found superior over Gypsum; FYM and PMC, when applied individually. Under sprinkler irrigation with alkali water of valley, a maximum and significant increase in seed cotton yield was recorded due to addition of Gypsum @.50\% GR + FYM@ 5.t ha-1 followed by Gypsum @ $50 \%$ GR +
PMC @ $2.5 \mathrm{t} \mathrm{ha}^{-1}$ and respective increases due to these combinations wre 46.5 and 44.5 per cent over control. Minhas et al. (1995) also noticed the sustained yields of rice-wheat with category I alkali water in presence of Gypsum and FYM in sandy loam soil.

Data pertaining to diagnostic characteristics of salt affected soil (depth 0.30 $\mathrm{cm}$ after harvest of cotton indicated that there was a decrease in $\mathrm{pH}, \mathrm{ECe}$ and SARe of salinesodic soil due to addition of Gypsum or FYM or $\mathrm{PMC}$ alone and in combinations under sprinkler irrigation with alkali water. However, a maximum and significant decline in these parameters were noticed due to Gypsum @ $50 \%$ GR+PMC@2.5 t followed by Gypsum@50\% GR+ FYM@5 t ha-1 . However, both the combinations were at par in respect of these attributes.

Table 1: Characteristics of Well Water of Purna Valley

\begin{tabular}{|c|c|c|c|c|c|c|c|c|}
\hline \multicolumn{5}{|c|}{ Summer 1997} & \multicolumn{4}{|c|}{ Winter 1997} \\
\hline Location & $\mathrm{ECe}$ & SAR & $\mathrm{RSC}$ & Class & $\mathrm{ECe}$ & SAR & RSC & Class \\
\hline \multicolumn{9}{|l|}{ Aloka Distt. } \\
\hline Karanja & 2.9 & 27.30 & 7.4 & Alkali & 2.1 & 24.4 & 2.8 & MAI \\
\hline Gandhi Gram & 1.4 & 13.10 & 5.5 & Alkali & 1.2 & 10.8 & 2.8 & MAI \\
\hline Kutasa & 0.35 & 12.45 & 3.80 & MAI & 0.27 & 9.20 & 4.7 & MAI \\
\hline \multicolumn{9}{|l|}{ Amravati Dist. } \\
\hline Naya Akola & 3.70 & 20.35 & 3.15 & MAI & 3.9 & 14.60 & 4.35 & Alkali \\
\hline Nimbhari & 2.82 & 16.7 & 9.4 & Alkali & 1.70 & 12.8 & 3.27 & MAI \\
\hline Dhamori & 0.5 & 11.35 & 4.5 & Alkali & 0.3 & 10.2 & 3.1 & MAI \\
\hline Kharte-legaon & 3.8 & 24.9 & 7.8 & Alkali & 3.1 & 19.20 & 4.7 & Alkali \\
\hline Chincholi & 1.76 & 13.17 & 4.5 & MAI & 0.90 & 12.9 & 3.7 & MAI \\
\hline Yewda & 3.8 & 22.41 & 6.5 & Alkali & 3.7 & 17.15 & 2.6 & MAI \\
\hline Antapur & 3.9 & 15.35 & 7.0 & Alkali & 3.1 & 15.0 & 4.5 & Alkali \\
\hline Khalkhuni & 2.2 & 14.8 & 6.1 & Alkali & 1.6 & 10.7 & 2.9 & MAI \\
\hline \multicolumn{9}{|l|}{ Buldhana Dist. } \\
\hline Shegaon & 1.35 & 13.2 & 2.6 & Alkali & 1.10 & 9.7 & 1.3 & MAI \\
\hline Kathora & 3.9 & 17.27 & 3.02 & Alkali & 3.2 & 13.1 & 2.55 & MAI \\
\hline
\end{tabular}

MAI- Marginally Alkali-1 MAII- Marginally Alkali -2

Table 2: Effect of amendments on seed cotton yield and soil characteristis

\begin{tabular}{|c|c|c|c|c|c|}
\hline \multirow[t]{2}{*}{ Treatments } & \multirow{2}{*}{$\begin{array}{l}\text { Seed cotton } \\
\text { yield } \\
\left(\mathrm{q} \mathrm{ha}^{-1}\right)\end{array}$} & \multirow{2}{*}{$\begin{array}{c}\text { \% increase } \\
\text { over } \\
\text { control }\end{array}$} & \multicolumn{3}{|c|}{ Soil characteristics } \\
\hline & & & $\mathrm{pHs}$ & $\begin{array}{l}\mathrm{ECe} \\
\mathrm{dsm}^{-1} \\
\left(\mathrm{dm}^{-1}\right)\end{array}$ & SARe \\
\hline Control & 18.51 & - & 8.21 & 2.03 & 16.20 \\
\hline Gyp 50\% & 26.25 & 41.8 & 7.84 & 1.84 & 11.76 \\
\hline Gyp $100 \%$ & 26.43 & 42.8 & 8.02 & 2.02 & 11.32 \\
\hline FYM & 22.42 & 21.1 & 7.94 & 2.00 & 12.05 \\
\hline PMC & 24.27 & 31.1 & 7.96 & 1.84 & 12.52 \\
\hline Gyp 50\% +FYM & 27.15 & 46.5 & 7.83 & 1.93 & 9.38 \\
\hline Gyp $50 \%+$ PMC & 26.74 & 44.5 & 7.79 & 1.85 & 10.49 \\
\hline $\mathrm{CD}(\mathrm{p}=0.05)$ & 3.20 & - & 0.09 & 0.10 & 2.70 \\
\hline
\end{tabular}




\section{Acknowledgement}

Authors are thankful to ICAR, New Delhi for providing necessary funds for experimentation.

\section{References}

CSSRI (1994) Research on Salt affected soils and Saline Water 1991-94; AICRP, CSSRI, Karnal 132001 (Haryana), p-8

Minhas, P.S.; Sharma, D.R. and Singh, V.P. (1995) J. Indian Soc. Soil Sci 43, 452.

Nimkar, A.M. : Deshpande, S.B. and Babrekar, P.G. (1992), Agropedology, 2, 59.
Richards, L.A. (Ed.) (1954). Diagnosis and Improvement of Saline and Alkali Soils, U.S. Dep. Agric. 60, P.160.

Sagare, B.N. Babhulkar, V.P. and Rane, P.V. (1996), State level seminar, Management of Problematic Soils, Akola hapt. Indian Soc. Soil. Sci. Dr. PDKV, Akola, p.18.

Shainberg. I. and Latey, J. (1984), Hilgardia, 52, 1 .

Tanapure, V.D. Barde, N.K. and Ballal, D.K. (1977). J. Maharashtra agric. Uni 2, 94. 